\title{
IMPLEMENTASI DAN EVALUASI KEPERAWATAN
}

\author{
Aswita Aprililian Sihaloho \\ aswita2002@gmail.com
}

\section{Latar Belakang}

Ilmu Keperawatan berdasarkan suatu teori yang sangat luas. Proses keperawatan adalah metode dimana suatu konsep diterapkan dalam praktik keperawatan. Hal ini bias disebut sebagai suatu pendekatan pemecahan masalah yang memerlukan ilmu, teknik, danketrampilan interpersonal dan melayani untuk memenuhi kebutuhan klien / keluarga. Proses keperawatan terdiri dari lima tahap yang sequensial dan berhubungan. Antara lain yaitu pengkajian, diagnosis, perencanaan, pelaksanaan, dan evaluasi. Tahap tersebut berintegrasi dalam mendefinisikan suatu tindakan perawatan. Salah satunya adalah implementasi atau pelaksanaan .Proses keperawatan menyediakan struktur praktis dengan penggunaan pengetahuan dan keterampilan yang dilakukan oleh perawat untuk eks presi kebutuhan perawatan (human caring). Keperawatan digunakan secara terus-menerus ketika merencanakan dan memberikan asuhan keperawatan

dengan mempertimbangkan pasien sebagai figur pusat dalam merencanakan asuhan

dengan priagobservasi respons pasien setiap tindakan sebagai penatalaksanaan dalam suatu asuhan keperawatan. Pada saat implementasi perawat harus melaksanakan hasil dari rencana keperawatanyang di lihat dari diagnosa keperawatan. Di mana perawatmembantu klien dari masalah status kesehatan yang induk kesehatan kestatus kesehatan yang lebih baik yang menggambarkan kriteria hasil yang diharapkan.Sehingga, dengan proses keperawatan, rasa tanggung jawab dan tanggung gugat bagi perawat itu Dapat dimiliki dan dapat digunakan dalam tindakan-tindakan yang 
merugikanatau menghindari tindakan yang legal. Semua tatanan perawatan kesehatan secara hukum perlu mencatat observasi keperawatan, perawatan yang diberikan, dan respons pasien.

\section{Metode}

Metode yang digunakan adalah literature review. Literature review ini menganalisis jurnal, text book, dan e-book yang relevan dan berfokus pada proses keperawatan sebagai metode dalam memberikan asuhan keperawatan.

Hasil

Dari beberapa Literature Review didapatkan bahwa penerapan asuhan keperawatan dikatakan baik apabila perawat sudah melaksanakan tahap-tahap dalam memberikan asuhan keperawatan kepada pasien yaitu: tahap pengkajian keperwatan, tahap diagnosa keperawatan, tahap perencanaan keperawatan, tahap implementasi keperawatan, dan tahap evaluasi keperawatan. Penugasan klinis mempunyai implikasi yang nyata bagi praktik keperawatan yaitu perawat akan mempunyai batas yang jelas dalam memberikan asuhan keperawatan kepada pasien. Pemberian kewenangan klinis juga bertujuan untuk melindungi keselamatan pasien dengan menjamin bahwa tenaga keperawatan yang memberikan asuhan keperawatan memiliki kompetensi dan kewenangan klinis yang jelas. ("Komite Keperawatan," 2013) Penugasan klinis juga merupakan payung hukum yang merupakan perlindungan bagi seorang perawat dalam melaksanakan tugasnya yaitu memberikan pelayanan keperawatan pada pasien sesuai dengan standar yang ditetapkan oleh Rumah Sakit dan Kode Etik Keperawatan Penelitian ini mengungkap manfaat penugasan klinis adalah mengetahui uraian tugas dari perawat dan mendapatkan kepastian dalam bekerja seperti tergambar dalam pernyataan 
partisipan berikut ini : "P5 : ...mendapatkan kepastian dalam bekerja mana tugas dan tanggungjawabnya". Pernyataan partisipan ini merupakan bagian dari upaya Rumah Sakit dalam menjalankan tugas dan tanggungjawabnya untuk menjaga keselamatan pasiennya adalah dengan menjaga standar dan kompetensi staf keperawatan yang akan memberikan pelayanan langsung kepada pasien. Manfaat penugasan klinis ini sebenarnya adalah untuk mewujudkan sistem peningkatan mutu Rumah Sakit, yang terdiri dari komponen quality assurance yakni setting standard, confirm to standards and continous quality improvement (CQI). Komponenkomponen ini saling berkaitan sehingga akan terwujud budaya kerja untuk menjamin mutu layanan keperawatan.

\section{Pembahasan}

\section{Evaluasi}

Evaluasi adalah suatu proses identifikasi untuk mengukur/menilai apakah suatu kegiatan atau juga program yang dilaksanakan itu sesuai dengan perencanaan atau tujuan yang ingin dicapai. Terdapat juga yang mengatakan bahwa arti evaluasi ini ialah suatu kegiatan atau aktivtias mengumpulkan informasi mengenai kinerja sesuatu (metode, manusia, peralatan), yang mana informasi itu akan dipakai untuk bisa menentukan alternatif terbaik didalam membuat keputusan.

Evaluasi tersebut sangat dibutuhkan didalam berbagai bidang kehidupan manusia sehingga meningkatkan efektivitas serta juga produktivitas, baik itu dalam lingkup individu, kelompok, atau juga lingkungan kerja. Dibawah ini merupakan beberapa informasi yang didapatkan dari proses evaluasi diantaranya sebagai berikut:

- Tingkat kemajuan suatu kegiatan.

- Tingkat pencapaian suatu kegiatan sesuai dengan tujuannya. 
- Hal-hal yang harus dilakukan di masa mendatang.

Evaluasi, yaitu penilaian hasil dan proses. Penilaian hasil menentukan seberapa jauh keberhasilan yang dicapai sebagai keluaran dari tindakan. Penilaian proses menentukan apakah ada kekeliruan dari setiap tahapan proses mulai dari pengkajian, diagnosa, perencanaan, tindakan, dan evaluasi itu sendiri. (Ali,2009)

Evaluasi dilakukan berdasarkan criteria yang telah ditetapkan sebelumnya dalam perencanaan, membandingkan hasil tindakan keperawatan yang telah dilaksanakan dengan tujuan yang telah ditetapkan sebelumnya dan menilai efektivitas proses keperawatan mulai dari tahap pengkajian, perencanaan dan pelaksanaan. (Mubarak, dkk., 2011)

Evaluasi disusun menggunakan SOAP dimana: (Suprajitno dalam Wardani, 2013)

S:Ungkapan perasaan atau keluhan yang dikeluhkan secara subjektif oleh keluarga setelah di berikan implementasi keperawatan.

O:Keadaan objektif yang dapat diidentifikasi oleh perawat menggunakan pengamatan yang objektif.

A: Analisis perawat setelah mengetahui respon subjektif dan objektif.P:

Perencanaan selanjutnya setelah perawat melakukan analisis.

Tugas dari evaluator adalah melakukan evaluasi, menginterpretasi data sesuai

dengan kriteria evaluasi, menggunakan penemuan dari evaluasi untuk membuat keputusan dalam memberikan asuhan keperawatan. (Nurhayati, 2011)

2. Implementasi 
Implementasi merupakan suatu penerapan atau juga sebuah tindakan yang dilakukan dengan berdasarkan suatu rencana yang telah/sudah disusun atau dibuat dengan cermat serta juga terperinci sebelumnya.

Pendapat lain juga mengatakan bahwa pengertian implementasi merupakan suatu tindakan atau juga bentuk aksi nyata dalam melaksanakan rencana yang sudah dirancang dengan matang. Dengan kata lain, implementasi ini hanya dapat dilakukan apabila sudah terdapat perencanaan serta juga bukan hanya sekedar tindakan semata.

Dari penjelasan itu kita dapat melihat bahwa implementasi bermuara pada mekanisme suatu sistem. Penerapan implementasi itu harus sesuai dengan perencanaan yang sudah dibuat supaya hasil yang dicapai sesuai dengan yang diharapkan.

Tujuan Implementasi dan Evaluasi

Tujuan implementasi:

Melakukan membantu atau mengarahkan kinerja aktifitas kehidupan sehari-hari. Memberikan arahan keperawatan untuk mencapai tujuan yang berpusat pada klien. Mencatat serta melakukan pertukaran informasi yang relevan dengan perawatan kesehatan yang berkelanjutan dari klien.

Tujuan evaluasi:

Melihat dan menilai kemampuan klien dalam mencapai tujuan. Menentukan apakah tujuan keperawatan telah tercapai atau belum.Mengkaji penyebab jika tujuan asuhan keperawatan belum tercapai.

Sumber: Asmadi (2008), Konsep Dasar Keperawatan, Jakarta: EGC.

Tahapan-Tahapan Implementasi:

Persiapan proses implementasi akan memastikan asuhan 
keperawatan yang efisien, aman, dan efektif.

1. Pengkajian ulang terhadap klien

Langkah ini membantu perawat untuk menentukan apakah tindakan keperawatan masih sesuai dengan kondisi klien.

2. Meninjau dan merevisi rencana asuhan keperawatan yang ada

Seteah mengkaji ulang, lakukan peninjauan rencana keperawatan, bandingkan data tersebut agar diagnosis keperawatan menjadi valid, dan tentukan apakah intervensi keperawatan tersebut masih menjadi yang terbaik untuk situasi klinis saat itu. Jika terjadi perubahan status klien, diagnosis keperawatn dan intervensinya, lakukan modifikasi rencana asuhan keperawatan. Rencana yang "ketinggalan zaman" akan menurunkan kualitas asuhan keperawatan. Proses peninjauan dn modifikasi memungkinkan perawat menyediakan intervensi keperwatn yang terbaik bagi kebutuhan klien. Modifikasi rencana perawat tertulis mencakup empat langkah sebagai berikut :

Lakukan revisi data pada kolom pengkajian untuk menggambarkan status klien terkini. Berikan tanggal pada data baru sehingga anggota tim yang lain mengetahui waktu perubahan tersebut.

Lakukan revisi pada diagnosis keperawatan. Hapus diagnosis keperawatan yang telah kehilangan relevansinya, tambah dan berikan tanggal pada diagnosis yang baru.

Lakukan revisi pada intervensi sesuai dengan diagnosis dan tujuan keperawatan yang baru. Revisi ini harus menggambarkan status terkini klien.

Tentukan metode evaluasi untuk menetukan apakah perawat telah berhasil.

3. Mengorganisasi sumber daya dan pemberian asuhan 
Sumber daya suatu fasilitas mencakup peralatan dan personel yang memiliki keterampilan. Organisasi peralatan dan personel akan membuat perawatan klien menjadi lebih tepat waktu, efisien, dan penuh keterampilan. Persiapan pemberian asuhan juga meliputi persiapan linggkungan dan klien untuk intervensi keperawatan.

4. Mengantisipasi dan mencegah komplikasi

Untuk mengantisipasi dan mencegah komplikasi, perawat mengenali resiko pada klien, menyesuaikan intervensi dengan situasi, mengevaluasi keuntungan terapi dibandingkan resikonya dan memulai tindakan pencegahan resiko.

5. Mengimplementasikan intervensi keperawatan

Implementasi intervensi keperawatan yang berhasil membutuhkan keterampilan kognitif, interpersonal, dan psikomotor.

Keterampilankognitif:

Keterampilan kognitif meliputi aplikasi keterampilan kognitif meliputi aplikasi pemikiran kritis pada proses keperawatan. Untuk melaksanakan intervensi dibutuhkan pertimbangan yang baik dan keputusan klinis yang jelas, ini berarti intervensi keperawatan tidak bersifat otomatis . perawat harus berpikir dan mengantisipasi secara kontinu sehingga perawat dapat menyesuaikan perawatan klien dengan tepat . perawat akan belajar mengintegrasikan berbagai konsep dan menghubungkannya sambil mengingat kembali fakta, situasi dan klien yang pernah perawat temui sebelumnya( Di Vito-Thomas, 2005 ).

Keterampilan interpersonal:

Keterampilan ini dibutuhkan untuk terwujudnya tindakan keperawatan yang efektif. Perawat membangun hubungan kepercayaan, menunjukan perhatian, dan berkomunikasi dengan jelas. 
Keterampilan psikomotorik:

Keterampilan psikomotor membutuhkan integrasi antara aktivitas kognitif dan motorik.

Sebagai contoh, saat melakukan pentuntuksn, perawat harus memahami anatomi dan farmakologi (kognitif), serta menggunakan koordinasi dan presisi untuk melakukan penyuntikan dengan tepat (motorik). Keterampilan ini sangat penting untuk membangun kepercayaan klien.

Sumber: Potter \& Perry. (2009). Fundamental of Nursing 7 th Edition.

Tahapan-Tahapan Evaluasi:

1. Mengidentifikasi kriteria dan standar evaluasi

2. Mengumpulkan data untuk menentukan apakah kriteria dan standar telah terpenuhi

3. Menginterpretasi dan meringkas data

4. Mendokumentasikan temuan dan setiap pertimbangan klinis 5. Menghentikan, meneruskan, atau merevisi rencana perawatan. Sumber: Potter \& Perry. (2009). Fundamental of Nursing 7 th Edition.

Macam-macam Implementasi:

Intervensi Keperawatan Independen:

Tindakan yang dilakukan perawat (nurse initiated intervention).

Tindakan ini tidak membutuhkan arahan dari profesional kesehatan lainnya (Wood, 2003). 
Intervensi Keperawatan Dependen:

Tindakan yang membutuhkan arahan dari dokter atau profesional kesehatan lainnya. Tindakan ini didasarkan pada respon dokter atau tenaga kesehatan untuk menangani suatu diagnosis medis.

Intervensi Keperawatan Kolaboratif:

Tindakan yang membutuhkan gabungan pengetahuan, keterampilan, dan keahlian berbagai profesional layanan kesehatan. Sumber: Potter \& Perry. (2009). Fundamental of Nursing 7 th Edition.

Macam Evaluasi:

Evaluasi formatif

Evaluasi formatif berfokus pada aktivitas proses keperawatan dan hasil tindakan keperawatan. Evaluasi formatif ini dilakukan segera setelah perawat mengimplementasikan rencana keperawatan guna menilai keefektifan tindakan keperawaatan yang telah dilaksanakan. Perumusan evaluasi formatif ini meliputi empat komponen yang dikenal dengan istilah SOAP, yakni subjektif (data berupa keluhan klien), objektif (data hasil pemeriksaan), analisis data (perbandingan data denagn teori), dan perencanaan.

\section{- Evaluasi sumatif}

Evaluasi sumatif adalah evaluasi yang dilakukan setelah semua aktivitas proses kepwrawatan seelsai dilakukan. Evalusi sumatif ini bertujuan menilai dan memonitor kualitas asuhan keperawatan yang telah diberikan. Metode yang dapat digunakan pada evaluasi jenis ini adalah melakukan wawancara pada akhir layanan, menanyakan respon klien dan keluarga terkait layanan keperawatan, mengadakan pertemuan pada akhir layanan. 
Ada tiga kemungkinan hasil evaluasi yang terkait dengan pencapaian tujuan keperawatan.

Tujuan tercapai jika klien menunjukkan perubahan sesuai dengan standar yang telah ditentukan.

Tujuan tercapai sebagian atau klien masih dalam proses pencapaian tujuan jika klien menunjukkan perubahan pada sebagian kriteria yang telah ditetapkan.

Tujuan tidak tercapai jika klien hanya menunjukkan sedikit perubahan dan tidak ada kemajauan sama sekali serta dapat timbul masalah baru.

Sumber: Asmadi (2008), Konsep Dasar Keperawatan, Jakarta: EGC.

Penutup

Kemampuan perawat pelaksana dalam implementasi kegiatan pendekatan manajemen berhubungan secara bermakna dengan peningkatan kemampuan klien dan kemampuan keluarga. Kemampuan perawat pelaksana dalam implementasi pemberian 
asuhan keperawatan isolasi sosial berhubungan secara bermakna dengan penurunan tanda gejala dan peningkatan kemampuan klien. Tahap evaluasi merupakan perbandingan yang sistematik dan terencana tentang kesehatan klien dengan tujuan yang telah ditetapkan, dilakukan berkesinambungan dengan ,melibatkan klien dan tenaga kesehatan lainnya. Evaluasi keperawatan mengukur keberhasilan dari rencana dan pelaksanaan tindakan keperawatan yang dilakukan dalam memenuhi kebutuhan klien. Implementasi keselamatan pasien dilakukan oleh perawat pelaksana adalah melakukan setiap tindakan sesuai dengan SOP, mengikuti pelatihan-pelatihan tentang keselamatan pasien. Keselamatan pasien merupakan hak setiap pasien yang mendapatkan pelayanan kesehatan di fasilitas pelayanan kesehatan. Keselamatan pasien (Pasient safety) rumah sakit adalah suatu sistem dimana membuat asuhan pasien lebih aman. Sistem tersebut meliputi asesmen resiko, identifikasi dan pengelolaan hal yang berhubungan dengan resiko pasien, pelaporan dan analisis insiden, kemampuan belajar dari insien dan tindak lanjutnya serta implementasi solusi untk meminimaliskan timbulnya resiko. Sistem tersebut diharapkan dapat mencegah terjadinya cidera yang disebabkan oleh kesalahan akibat melaksanakan suatu tindakan atau tidak melakukan tindakan yang seharusnya dilakukan. (Panduan Nasional Keselamatan Pasien Rumah Sakit, Depkes RI, 2006). 


\section{DAFTAR PUSTAKA}

Indonesia, P. P. N. (2005). Standar Praktik Keperawatan Indonesia. Jakarta: PPNI.

Purwanto, E. (2011). Implementasi dan Evaluasi Keperawatan.

Supratti, S., \& Ashriady, A. (2018). Pendokumentasian Standar Asuhan Keperawatan Di Rumah Sakit Umum Daerah Mamuju. Jurnal Kesehatan Manarang, 2(1), 44-51.

Ernawati, N. (2019). Implementasi dan Evaluasi Keperawatan Dengan Pendekatan Kasus: Modul 3.

Tuharea, N. A., Payung, D. S., Purnawinadi, I. G., \& Rotikan, R. (2019). Sistem komputerisasi untuk pencatatan laporan asuhan keperawatan untuk mahasiswa ilmu keperawatan. Creative Information Technology Journal, 4(4), 245-253.

Bara, M., \& Suryati, B. (2014). Hubungan motivasi perawat dengan pelaksanaan pendokumentasian asuhan keperawatan di Ruang Rawat Inap RSUD Pasar Rebo. Jurnal Health Quality, 5(1), 1-66.

Astar, F., Tamsah, H., \& Kadir, I. (2018). Pengaruh Pelayanan Asuhan Keperawatan terhadap Kepuasan Pasien di Puskesmas Takalala Kabupaten Soppeng. YUME: Journal of Management, 1(2).

APRILYANI, C. E. (2016). ASUHAN KEPERAWATAN PADA KLIEN DENGAN PENYAKIT JANTUNG KORONER DI RSUD Dr. WAHIDIN SUDIRO HUSODO MOJOKERTO. KTI D3 KEPERAWATAN.

Muryani, M., Pertiwiwati, E., \& Setiawan, H. (2020). KUALITAS PENDOKUMENTASIAN ASUHAN KEPERAWATAN DI RUANG RAWAT INAP (Studi di RSUD Kalimantan Tengah). NERSPEDIA JOURNAL, 2(1), 27-32. 
Rkt, E. Y. S. (2019). Tahapan-tahapan Dokumentasi Dalam Asuhan Keperawatan.

Yusuf, A., Fitryasari PK, R., \& Nihayati, H. E. (2015). Buku ajar keperawatan kesehatan jiwa.

Butar-Butar, J., \&Simamora, R. H. HubunganMutuPelayananKeperawatandengan Tingkat KepuasanPasienRawatInap di RSUD PandanKabupatenTapanuli Tengah. JurnalNers Indonesia, 6(1), 50-63.

Simamora,

R.

$\mathrm{H}$. (2005). HubunganPersepsiPerawatPelaksanaTerhadapPenerapanFungsiPengorgani sasian Yang DilakukanOlehKepalaRuanganDenganKinerjanyaDiruangRawatInap RSUD Koja Jakarta Utara (Doctoral dissertation, Tesis FIK UI, Tidakdipublikasikan). 